\title{
The Nation, Delegation, and Constitutional Change in Poland
}

\author{
AgNiEsZKa Bień-KaCAŁA* \\ ANNA TARNOWSKA** \\ WOJCIECH WŁOCH ${ }^{* * *}$
}

\begin{abstract}
This paper presents results of research on legislative delegation in representative democracy which points to the existence of a bond between a nation (demos) and a constitution. Consequently, we claim that the meaning of constitutional institutions may change, depending on the understanding of the concept of nation. We refer to a homogeneous and to a heterogeneous concept of nation and their coexistence in Polish societal space and analyse the Second (1918-1939) Polish Republic's constitutions and practice to exemplify the friction of two concepts of the nation. Furthermore, the Third (since 1989) Republic's regulations and practice are explored to show how a homogeneous concept of the nation affects the openness of 1997 Constitution. A heterogeneous nation is reflected in the Polish constitutions and their values whilst at the same time, a constitutional practice has been developed under influence of the homogeneity of the nation.
\end{abstract}

Keywords: nation, homogeneity, heterogeneity, delegation, constitution, constitutional change

\section{INTRODUCTION}

In this paper ${ }^{1}$ the meaning of a nation, democratic delegation (Section 2), and the classical concept of a representative system (Section 3 ) are presented and followed by a description of the two ideal concepts of the nation: homogeneous and heterogeneous (Section 4). This is then put in the context of democracy (Section 5). The theoretical part of the paper is developed by asking the question whether a nation could be seen as an enemy or a friend of democracy (Section 6). Both concepts can be found also in Polish political thought (Section 7). An explanation of the theoretical problem is illustrated by a variety of examples rooted in the periods of the Second (Section 8) and Third Republic of Poland (Section 9). The paper ends with a brief conclusion (Section 10).

\section{NATION AND CHAIN OF LAW-MAKING DELEGATIONS}

The notion of delegating in the a priori sense, the transfer of legislative authority, is related to modern theories of the social contract that justifies the thesis of the sovereignty of the people and the derivative nature of political power. Democratic law-making may only be considered as an element of 'a chain of law-making delegations'. According to the theory of democracy, the original law-making competence ascribed to a nation (demos - people or citizens) $)^{2}$ is realized through a number of law-making acts - from general norms to the

* Prof UMK, dr hab, Nicolaus Copernicus University, Toruń, Poland, abien@umk.pl.

** Assistant Professor, Nicolaus Copernicus University, Toruń, Poland, atarn@umk.pl.

*** Nicolaus Copernicus University, Toruń, Poland, wloch@umk.pl.

1 The article has been prepared as part of the grant-supported project 'Law-making delegation in representative democracy' financed by the National Centre of Science, contest Opus 11, registration no. 2016/21/B/HS5/00197.

2 The term 'nation' is used here to denote the most important subject of democratic legitimacy. 
execution of an individual decision. The notion of representative democracy means that the sovereignty of the people is realized through its delegation onto political representatives (individual politicians or parties) with the citizens entrust representatives with their original law-making competences. ${ }^{3}$ That leads to the question what constitutes the bond of delegation in a representative democracy? The question is connected to the problem of legal and theoretical justification for taking actions in the name of the nation by the parliamentary majority. Art. 104 of the Constitution of the Republic of Poland of $1997^{4}$ provides that the MPs are the representatives of the entire Nation, not only their voters.

K. Strøm, W. C. Müller and T. Bergman describe delegation within democratic politics as a process of delegating. Within the process, the entity with the authority to make political decisions (the people - the sovereign authority) conditionally points to the entities that make decisions on their behalf (representatives). ${ }^{5}$ In such a model, all levels of taking political decisions ought to be oriented to the preferences of the citizens. The election of representatives in general elections that fulfil specific democratic criteria may be viewed as a specific embodiment of such a delegation as well as a form of holding them responsible. Democratic politics within the system of representation creates a specific 'chain of representation' as follows:

1. Delegation from voters to their elected representatives.

2. Delegation from legislators to the executive branch, specifically to the head of government (the Prime Minister).

3. Delegation from the head of government (Prime Minister) to the heads of different executive departments.

4. Delegation from the heads of different executive departments to civil servants. ${ }^{6}$

A 'chain of responsibility' can be obtained by reversing the chain in an appropriate manner. Citizens only directly delegate representatives to a given legislative authority, whereas the remaining links of the chain ought to be viewed as indirect delegation. However, the model reflects only the formal aspect of delegation. The question arises whether the established interpretation of the first element of the 'chain of representation' affects the understanding of the entire 'chain'. Does the established interpretation of the nation determine the form of the system that is relevant for it? Does the change in understanding the nation entail a change in understanding and using the norms enshrined in the constitution? A positive answer would mean that the concept of a nation is an essential element of constitutional identity for any democratic system, including the Republic of Poland. If it is feasible to employ different means of interpretation to the same form of 'chain of representation', then changing the meaning of the concept of nation may be equivalent to a material change of constitution, while retaining the validity of its provisions. The change that takes place in human minds might be more important than what remains on the normative plane.

3 Dahl (1989) chapter 15. On the beginning and transformation of the 'representative government', see Manin (1997).

${ }^{4}$ Konstytucja Rzeczypospolitej Polskiej (Dz.U. Nr 78, poz. 483) [Constitution of the Republic of Poland (Journal of Laws Number 78, item 483)].

5 Strøm, Müller and Bergman (2006).

6 Strøm, Müller and Bergman (2006) 20. 


\section{NATION AND CLASSICAL CONCEPTS OF THE REPRESENTATIVE SYSTEM}

The importance of the concept of the 'nation' is manifested in the classical concepts of the representative system. The formulation of a basic principle of contemporary democracy can be found in the work of Immanuel Kant:

Yet a public law which determines for all what they are legally allowed and not allowed to do is an act of a public will from which all right issues and which therefore must not be able to do anyone wrong. But this is possible only with the will of the entire people (since all decide over all, and hence each decides over himself). ${ }^{7}$

Democratic legislation must be based on the will of the people and represent a contrast to the particular will. The principle that legislation comes from the common will 'obligates every legislator to pass laws in such a way that they would have been able to arise from the united will of an entire people and to regard every subject, insofar as it wishes to be a citizen, as though it has given its assent to this will. ${ }^{8}$ Legislation institutions should 'represent the people', i.e. act on its behalf and according to its will. The people are the superior (principle), and legislation is its representative (agent).

'Government by proxy' (gouvernement exercé par procuration), according to Sieyès, ${ }^{9}$ is a result of social development and the increase of the society, which makes it impossible for direct democracy to form..$^{10}$ Representative institutions must be set up when it is not possible to directly establish the 'common will'. They are based on three principles:

firstly, the community does not divest itself of the right to will. This right is its inalienable property. All it can do is to entrust the exercise of that right to someone else. [...] Secondly, the body of those delegated to exercise that trust cannot even enjoy the full exercise of the community's power. The community can entrust only that portion of its total power that will be needed to maintain good order. In this kind of delegation, nothing more than what is necessary is surrendered. Thirdly, it is not up to the body of delegates to alter the limits of the power with which it has been entrusted. It is easy to see that it would be self-contradictory to grant it this kind of faculty. ${ }^{11}$

This way, the 'common will' transforms into the 'representative common will' (volonté commune représentative):

firstly, that will, as expressed by the body of representatives, is neither complete nor unlimited; it is no more than a portion of the great common national will. Secondly,

7 Kant (2006) 49.; Habermas (1996) 89-90., 93-94.; Przeworski (2010) 8-9.

8 Kant (2006) 51.

9 Sieyès (2003) 134.

10 Sieyès (2003) 147 footnote, where Sieyès points to the fact that direct democracy is not possible in a 'numerous nation'. Like Kant and the Federalists, he juxtaposed direct democracy in opposition to the representative system (The Federalist No. 10), Hamilton, Madison, Jay (2003) 44.; Kant (2006) 76-78. Till the end of the nineteenth century the term 'democracy' was bound up with the concept 'direct democracy', see Saward (2003) chapter 3.

11 Sieyès (2003) 134-35. 
those delegated to exercise that will do not do so as a right that is their own, but as a right exercised on others' behalf. The common will is exercised as a delegation or trust. $^{12}$

Political representation of the nation or people is based on 'what they have in common', and its goal should be 'the common interest'. ${ }^{13}$ Sieyès argues that individuals, as citizens, have common interests which are independent of their individual differences and particular interests as private persons, thus individuals can only be represented as citizens and not as private persons. ${ }^{14}$ The representative system assumes a certain bond between citizens which does not consist in the private interests (of the individual) and particular interests (of the group) coinciding with one another.

John Stuart Mill believes that such a bond ensures nationality, 'where the sentiment of nationality exists in any force, there is a prima facie case for uniting all the members of the nationality under the same government, and a government to themselves apart. This is merely saying that the question of government ought to be decided by the governed.'15 Nationality may take on different forms and it may be conditioned by various causes, but most importantly it integrates individuals 'by common sympathies, which do not exist between them and any others - which make them co-operate with each other more willingly than with other people, desire to be under the same government, and desire that it should be government by themselves or a portion of themselves, exclusively. ${ }^{16}$ Nationality thus becomes the basis for representative democracy, since it connects individuals with a specific bond enabling them to perceive themselves as an entity which, on the one hand, 'wants' to function as a state, and, on the other hand, legitimises a specific form of the political system and current political activities. A shared sense of nationality is intended to ensure sustainability for democracy because, regardless of whether one belongs to a minority or a majority, to the ruling party or to the opposition, to the upper social class or to the lower social class, it makes one want to be a member of a state and be subordinated to its laws.

\section{TWO IDEAL TYPES OF NATION - HOMOGENEOUS AND HETEROGENEOUS}

One might ask about the nature of this 'sentiment of nationality' and how it influences the understanding of the democratic system. ${ }^{17}$ It is useful to employ Weber's ideal types in order to analytically explicate the concept of nation and its basic meanings.

An ideal type is formed by the one-sided accentuation of one or more points of view and by the synthesis of a great many diffuse, discrete, more or less present and occasionally absent concrete individual phenomena, which are arranged according to those one-sidedly emphasized viewpoints into a unified analytical construct. ${ }^{18}$

12 Sieyès (2003) 135.

13 Sieyès (2003) 155.

14 Sieyès (2003) 156.

15 Mill (1977) 547., Canovan (2005) chapter 3.1.

16 Mill (1977) 546.

17 The question can be answered in two ways: (a) empirically by examining how a society understands the concept of nationality and how it affects political practice; or (b) analytically by examining the concept of 'nation' and its attitude to 'democracy' or 'constitution'. In this paper we elaborate the second way.

18 Weber (1949) 90. 
The role of ideal types as intellectual models is a better understanding of social phenomena rather than justifying them. Ideal types are ideal in the analytical rather than normative sense. They are not laws but they capture certain 'one-sided' phenomena; they are neither true or false, but rather useful or not useful. An ideal type is an intellectual construct.

It has the significance of a purely ideal limiting concept with which the real situation or action is compared and surveyed for the explication of certain of its significant components; such concepts are constructs in terms of which we formulate relationships by the application of the category of objective possibility. By means of this category, the adequacy of our imagination, oriented and disciplined by reality, is judged. ${ }^{19}$

The literature distinguishes two ideal types of the nation, which are opposed to each other when considered as ideal types, but in social reality they coexist in varying proportions. ${ }^{20}$ One may dominate in a given society. The domination of a certain type can influence how a given empirical nation interprets democracy as a system that provides the nation's subjectivity and enables it to influence the public and political sphere. Besides, the dominant concept changes with time. The changes may be determined by historical events, by the influence that they have on national identity, and by the shaping of national characteristics of a given community.

The first ideal type of the nation may be defined as a homogeneous nation. National identity in this sense is associated with a certain condition of homogeneity based on specific 'characteristics' that make it possible to distinguish 'natives' from 'strangers'. In such a perspective the nations perceive 'blood, soil, ethnolinguistic peoplehood, and religion as necessary or at least central elements of a national identity. ${ }^{, 21}$ The stress here is laid on 'homogeneity and on cultural assimilation to the dominant paradigm.'22 The homogeneous nation appears to be founded on 'the prepolitical unity of a community with a shared historical destiny. ${ }^{23}$ This type of meaning stresses the ethnic and/or cultural homogeneity of national identity - 'nations are communities of people of the same descent, who are integrated geographically, in the form of settlements or neighborhoods, and culturally by their common language, customs, and traditions. ${ }^{24}$ The second type may be referred to as a heterogeneous nation. Nationality here is based on a community of political ideals and goals. As opposed to the notion based on homogeneity, the nation is understood as a political community that leaves 'the door open a crack, since they allow anyone in who can join in the project of 'life, liberty, and the pursuit of happiness' - or, in the case of India, of economic equality - that defines the national aspiration. ${ }^{25}$ Nationality is understood as 'membership in terms of shared goals and ideals, thus in a way that does not require homogeneity - in dress, dietary custom, religious belief, or even outward religious observance.' ${ }^{26}$ A heterogeneous nation is a nation of citizens. Understood like this, "the nation is the bearer of sovereignty. [...] The intentional democratic community

\footnotetext{
19 Weber (1949) 93.

20 Bryant (1995) 145.

21 Nussbaum (2012) 13.

22 Nussbaum (2012) 14.

23 Habermas (1996) 492.

24 Habermas (1996) 494.

25 Nussbaum (2012) 16.

26 Nussbaum (2012) 18.
} 
(Willensgemeinschaft) takes the place of the ethnic complex. ${ }^{27}$ Politically speaking, a nation becomes the "constitutive feature of the political identity of the citizens of a democratic polity': 'the nation of citizens finds its identity not in ethnic and cultural commonalities, but in the practice of citizens who actively exercise their rights to participation and communication. ${ }^{28}$ The first ideal type is constituent for the concept of 'nation state' (Nationalstaat), whereas the other for the 'state nation' (Staatsnation). In this context, a distinction can be made between the legitimacy of legislation based on the common will of a homogeneous nation and that based on commonly accepted procedures. In the former, the result of legislation is predetermined by the presumed content of this will, whereas in the latter, the procedures are fixed and their outcome is variable.

\section{NATION AND DEMOCRACY}

As Schnapper points out, the second ideal type has a strictly political meaning. She distinguishes between nation and ethnicity, the former is an organised group of political importance, while ethnic groups are linked by a community of history and culture. ${ }^{29}$ The nation is political by principle, whereas identity of ethnic groups does not necessarily imply political expression. 'Like any political unit, the nation, is defined by its sovereignty, exercised internally to integrate the populations that it includes and, externally, to assert itself as an historical subject in a global order founded on the existence and relations between politically constituted nations. But its uniqueness is that it integrates populations in a community of citizens, whose existence legitimates the internal and external action of the state. ${ }^{30}$ By adopting that interpretation, it is the heterogeneous concept of nation that binds civic integration with the legitimization by the principle of 'sovereignty of a nation'.

The citizenship binds individuals and social groups together in a nation and the citizens legitimise the actions of a state. 'Civic nations', writes Bryant, 'may attribute a leading role in their formation to one or more particular ethnics but they also extend citizenship to all who permanently and lawfully reside within their territory and who join in the national imaging or at least refrain from contesting it. By definition they are pluralist and/or assimilationist. Ethnic nations, by contrast, relate citizenship and full participation in society to ethnicity and descent. They can and do develop civil societies but these are exclusive; residents of other ethnic origins, even of long standing, are denied citizenship. There is a suspicion of difference and a rejection of pluralism. ${ }^{31}$

This perspective outlined in such a manner means, paraphrasing John Rawls, that the political nation is neither a community nor an association - it does not constitute a homogeneous whole, nor does it disintegrate to isolated monads. A nation of citizens may be united by an affirmation of principles on which a democratic constitution is based. A constitution that guarantees individual freedom and laws of political membership, and establishes procedures of making political decisions. ${ }^{32}$ It might be said that the bond which

27 Habermas (1996) 495.

28 Habermas (1996) 495-96.

29 Schnapper (1998) 16.

30 Schnapper (1998) 16.

31 Bryant (1995) 145.

32 Rawls (1993) 40-43. and 158-64. Cf. the distinctions between universalist and particularistic 'constitutional essentials' introduced by the authors in Nation - delegation - Constitution. Reconsidering the Role of Religion in Polish Identity Development. 
unites the democratic political nation consists in the affirmation of civic equality and pluralism as well as in the special role of constitution, ${ }^{33}$ as it defines the form and boundaries within which the legislator may fulfil the legislative function that it was 'entrusted with by the nation'.

The offered interpretation can be contrasted with a different concept of democracy, which emphasizes that homogeneity is the factor that transforms a society into a political entity. Carl Schmitt's proposition is that

'every actual democracy rests on the principle that not only are equals equal but unequals will not be treated equally. Democracy requires, therefore, first homogeneity and second - if the need arises - elimination or eradication of heterogeneity. ${ }^{34}$

Democracy is based on the homogeneity of the nation and as such involves the acknowledgement of the 'will of nation' as the source of law. Legislative institutions of representative democracy do not represent individual groups, but a nation as a whole (an idea of a nation). ${ }^{35}$ If the homogeneity of a nation is accepted as a foundation of democracy then the parliamentary majority does not express the will of part of the nation, but of the whole of the nation. The democratic identity of the governing and the governed means that there is a bond between the will of the representatives and the "will of the homogeneous people'. ${ }^{36}$ In a homogeneous democracy there is no exact place for a minority or opposition - 'one must assume that, by virtue of being a part of the same people, all those similarly situated would in essence will the same thing'. ${ }^{37}$ Democracy of this kind is not a 'dictatorship of the majority' as it simply refuses a national affiliation to 'what is different' and thus removes all heterogeneous elements, which is why it can be described as 'the rule of the whole'.

If the nation is understood as the essential substantive element of democratic equality, practical consequences of a special type result. A democratic state that finds the underlying conditions of its democracy in the national similarity of its citizens

33 'Citizens have to be attached, in the first place, to the very idea of a constitution - or, if one wanted to rephrase this in order not to keep overburdening the notion of 'constitution', the idea of committing oneself to mutual justification in a well-ordered society with fair terms of cooperation and fair terms of limiting power', Müller (2007) 54.

34 Schmitt (2000) 9. Democracy in this sense can be linked to nationalism: 'nationalism is about entry to, participation in, identification with, a literate high culture which is co-extensive with an entire political unit and its total population, and which must be of this kind if it is to be compatible with the kind of division of labour, the type or mode of production, on which this society is based', Gellner (1983) 95. 'Every high culture now wants a state, and preferably its own. Not every wild culture can become a high culture, and those without serious prospects of becoming one tend to bow out without a struggle; they do not engender a nationalism. Those which think they do have a chance - or, if anthropomorphic talk about cultures is to be avoided, those whose human carriers credit them with good prospects - fight it out among themselves for available populations and for the available state-space. This is one kind of nationalist or ethnic conflict', Gellner (1983) 51.

35 Schmitt (1996) 25-27.

36 Schmitt (2004) 24.

37 Schmitt (2004) 28. Schmitt's thesis presented above is a polemic with Kelsen, who argued that democracy must, out of necessity, be based on relativism and pluralism, Kelsen (1948) 906-914. 
corresponds to the so-called nationality principle, according to which a nation forms a state, and a state incorporates a nation ${ }^{38}$

Democratic legitimacy gives legislation the characteristics of 'truthfulness and fairness' which stem from the will of the whole nation, without which it would merely become a form of one part of society ruling over the other. However, this identity of the will of the whole people excludes everything that is not in accord with it. A nation in a homogeneous sense is considered as a political entity and therefore is an exclusive nation. ${ }^{39}$ Any departures from 'national identity' are treated not only as 'being different' but also as something potentially 'unfriendly'. In fact, the homogeneous national political identity is shaped in relation to what is different, and thus treated as enemy. ${ }^{40}$ For a nation in a homogeneous sense, the constitution does not serve as a medium of integration because a nation is perceived as a unity without it. Its function is to ensure a democratic legislative procedure as an a priori homogeneous nation is characterised by a 'common will'. The actual and fundamental constitution is the will of the nation to which a formal constitution is just something recycled and accidental. If the united people are an absolute basis of the system then it could be said in reference to Rousseau that

there is not, nor can there be, any kind of fundamental law that is binding upon the body of the people, not even the social contract. [...] Now, the sovereign, being formed solely by the individuals who compose it, neither has nor can have any interest contrary to theirs; thus the sovereign power need make no guarantee to its subjects, because it is impossible for the body to wish to harm all its members [...]. The sovereign, for the simple reason that it is so, is always everything that it should be. ${ }^{41}$

The will of the people understood as a 'common will' is the definitive and decisive reason.

\section{NATION - ENEMY OR FRIEND OF DEMOCRACY?}

Lefort points out that openness and changeability are constituent for modern democracy and contrary to a homogeneous concept of democracy. Any attempts to make it closed and

38 Schmitt (2008) 262.

39 'By stressing that the identity of a democratic political community hinges on the possibility of drawing a frontier between 'us' and 'them', Schmitt highlights the fact that democracy always entails relations of inclusion-exclusion', Mouffe (2000) 43. In this sense, a heterogeneous nation is not entirely open either, but rather conditionally open: it requires citizens to accept the basic principles of a democratic constitution. However, apart from this condition, he allows for a variety of lifestyles, religions and world views. The homogeneous concept of a nation emphasises the identity of its members, which should be more important than democratic procedures.

40 'The distinction of friend and enemy denotes the utmost degree of intensity of a union or separation, of an association or dissociation. (...) he is, nevertheless, the other, the stranger; and it is sufficient for his nature that he is, in a specially intense way, existentially something different and alien, so that in the extreme case conflicts with him are possible. These can neither be decided by a previously determined general norm nor by the judgment of a disinterested and therefore neutral third party', Schmitt (1996) 26-27.

41 Rousseau (2002) 165-66. 
determined, e.g., by referring to the whole nation's will, leads to totalitarianism. ${ }^{42}$ Pluralism and political rivalry cause the democratic form (political regime) and substance (legislation acts) to be dynamic and indefinite. No current political power may claim the right to represent the 'whole of the nation's will'. In democracy

the exercise of power is subject to the procedures of periodical redistributions. It represents the outcome of a controlled contest with permanent rules. This phenomenon implies an institutionalization of conflict. The locus of power is an empty place, it cannot be occupied - it is such that no individual and no group can be consubstantial with it - and it cannot be represented. ${ }^{43}$

Homogeneous 'national unity', however, strives to fill the 'empty place of power' that was abandoned by a monarch who had a transcendent legitimisation and authority. Democracy based on a homogeneous concept of the nation in fact prejudges that legislation must 'reflect' a national unity. A homogeneous national identity fully determines political systemic identity and differentiates it from other political national identities. It could be said that both the substance and the form of homogeneous democracy is closed and permanent, if that is the nation's will.

Modern-day populism refers to the homogeneous idea of a nation. According to Müller, populism is characterised by highlighting the difference between a 'pure and united nation' and 'treacherous elites' which lead to anti-pluralism. It is only the populists that represent the nation as a whole, and therefore any opposition to them is not legitimate and is anti-national. ${ }^{44}$ As a consequence, 'the true nation' is in fact a certain part of the ethnic or political nation - the part which has been deemed 'pure and united' and represented by a given populist movement. All those who stand in opposition to them act against the 'idea of the nation' and against 'national ethics'. They go from political adversaries to the enemies of the nation. The homogeneous concept of a nation is in fact intended to justify the hegemony of a certain political power which sees itself as the only representative of a 'true nation', whose alleged will and well-being make the true constitution.

Therefore, is it appropriate to recognise the very concept of a nation, no matter how it is understood, as so dangerous that the only hope for the democracy would be the pursuit of 'post-national democracy'? ${ }^{45}$ Mounk believes that at a time when the vision of the emergence of post-national democracies is becoming increasingly distant and unlikely to be materialised, it is necessary to 'domesticate nationalism' in the form of an open national identity - inclusive and pluralised. The concept of the nation itself under present conditions is impossible to be simply eradicated from the present-day democratically imagined world. A post-national utopia cannot become a counter-proposal for populist nationalism. Rather, it could be a heterogeneous nation based on the ideals of equality, freedom, and participation. Thus, political entities must take these ideals serious because the success of nationalist populism is due, among other things, to the fact that they are not always implemented satisfactorily in practice. ${ }^{46}$ Hence, there is a need for returning to 'state patriotism' which is

42 Lefort (1988) 13.

43 Lefort (1988) 17.

44 Müller (2016) chapter 1.

45 See for example Guérot (2016) chapter 2.

46 Mounk (2018) chapter III. 7. 
based on the idea of state that exercises power in the name of a sovereign people. A nation understood as a 'sovereign people' is a collection of citizens with political rights who made the state to be treated as their 'own' ${ }^{47}$ The political and heterogeneous nation of citizens constitutes a nation as 'a body of associates living under a common law, represented by the same legislature' ${ }^{48}$

Further analysis is required to determine an answer to whether the homogeneous or heterogeneous concept of a nation is reflected in Polish political thought and in independently adopted constitutions throughout the history of the $20^{\text {th }}$ and $21^{\text {st }}$ centuries.

\section{ROMAN DMOWSKI OR KAZIMIERZ KELLES-KRAUZ?}

In Polish political thought, examples of both types of ideal nation can be found. The most outstanding representative of Polish nationalism, Roman Dmowski, ${ }^{49}$ pointed out that the most important political value is not the issue of the state constitution or civil rights, but 'the nation itself as a living social organism, which has developed its own spiritual identity, its own culture on the basis of its race and its history. ${ }^{50}$ The most important goal of a nationally conscious individual, on the other hand, is to 'expand a national life, proliferate the material and spiritual well-being of the nation, obtain the highest possible position in the line of the peoples for this social whole. ${ }^{51}$ In such a perspective, the duties towards the nation have priority over all the others. ${ }^{52}$

The national bond constitutes a particular 'national ethic' which 'forms the strongest of the great moral relationships known to mankind, the breaking of which, when properly established, ceases to depend directly on the will of the individual ${ }^{53}$ and formulates the imperative of 'thinking and acting as is necessary for the preservation and development of the essence of the national whole. ${ }^{54}$ A nation organized into a state must first of all strive to ensure national unity and the identity of the whole. For this purpose, it must exclude from the national community all groups and individuals that threaten it and in relation to other states, pursue a policy of absolute support for the goals of the nation and its dominance over other nations. 'The state', as Dmowski writes, 'can only create a healthy, strong, populous nation which has a significant individuality, which is cohesive and strongly attached to its uniqueness. The Polish state will primarily create a Polish nation, composed of indigenous Polish people, living the Polish culture. ${ }^{55}$ All social and political conflicts within a nation must give way to a 'national ethic'. The highest value of this ethics is the nation as a whole and unity itself.

47 Hobsbawm (2000) 86-88.

48 Sieyès (2003) 97.

49 R. Dmowski (1864-1939) was an outstanding and influential Polish politician and a nationalist thinker. For an English-speaking reader, the following work may be of interest Walicki (2000).

50 Dmowski (2014) 75.

51 Dmowski (2014) 75.

52 Dmowski (2014) 769.

53 Dmowski (2014) 106.

54 Dmowski (2014) 108.

55 Dmowski (2014) 77. 
A different concept of the nation was formulated by an outstanding democratic socialist Kelles-Krauz ${ }^{56}$ who did not diminish the significance of cultural, historical and linguistic national identities, but attributed to their existence a key role in the creation of bonds of solidarity between individuals and social classes. However, he did not claim that the nation is an absolute goal in itself. 'People cannot join into a society and participate in the granting of laws for themselves which would be generally binding throughout the globe or in one part of the world, but they must be divided into a number of societies which, in turn, may enter into different relationships of interdependence, but which must govern themselves independently. [...] Nationality can be the only logical basis for dividing the world into societies, which is in turn an indispensable condition for an effective exercise of the logical human right to self-government and the accompanying duty to submit to the will of the majority.' 57

Conflicts and rivalry based on political, economic, and ideological differences do not disappear within the nation. National identity manifests itself in the fact that the 'entire nation' recognises the existence and importance of the 'interest for the benefit of the nation'. An important function of national identity is that it allows one to experience the bonds between differing citizens or social classes. National identity does not have to be closed and confrontational. Kelles-Krauz points out that nationality is tied to the idea of equality in the sense that every nation has an equal right to existence and development. ${ }^{58}$ Democracy based on a national identity does not negate social or political pluralism - 'classes of the modern age are conflicting, but this means, as logicians argue, that they have a common ground between them, that they are not alien to each other.' ${ }^{59}$ Democracy is a specific method of conflict resolution within a given national state. Therefore, the dominance of a certain majority is changeable and dynamic. The minority is not set outside political rivalry, nor is it treated as having betrayed 'national ethics'. Similarly, national minorities are not excluded from the civic community upfront. This is where the difference between Dmowski's homogeneous concept and Kelles-Krauz's heterogeneous concept is particularly evident. Dmowski points out that a homogeneous nation may only assimilate such national minorities as will have a favourable effect on its strength and power. The fact that they do not have a 'crystallised identity' is a preliminary condition. If a minority has a highly developed national consciousness, it a priori becomes a rival that threatens the majority, as exemplified by the Jewish minority in Dmowski's case. ${ }^{60}$ Kelles-Krauz points out, regarding the 'Jewish issue', that national minorities (and therefore also Jews) can be included in the civic community by granting them equal rights. Within a democratic system, national minorities can have both an equal right to form their own national identity and an equal right to political participation. ${ }^{61}$ This way a democratic state becomes a medium that intervenes not only between different classes but also different national identities.

56 K. Kelles-Krauz (1892-1905) was an outstanding (albeit less-remembered today) thinker and a socialist activist. For an English-speaking reader, the following work may be of interest Snyder (1997).

57 Kelles-Krauz (1989) 303.

58 Kelles-Krauz (1989) 317-18.

59 Kelles-Krauz (1989) 351.

60 Dmowski (2014) 98., 103. and 139.

61 Kelles-Krauz (1989) 330-33. 
It could be said that Dmowski's homogeneous concept subordinates all political and systemic issues to the exclusive well-being of a nation as a whole while Kelles-Krauz's heterogeneous concept points to the need for democratic mechanisms, since nations are internally pluralistic and need methods of conflict resolution and political decision making. A heterogeneous democracy needs a constitution that would serve as an integrative medium between citizens, social groups, classes, and minorities. Social diversity needs a constitution as a medium that enables a democratic decision-making, and open nationality as a foundation of national belonging and a civic bond.

\section{SECOND REPUBLIC (1918-1939): BETWEEN DEMOCRATIC AND AUTHORITARIAN CONSTITUTIONS}

The Polish state reborn in 1918 after the First World War continued to have a multinational, ${ }^{62}$ multicultural, and multidenominational character. The first systemic consideration was only temporary. The single-chamber parliament elected in January 1919 adopted in February the Small Constitution. ${ }^{63}$ The act was indeed concise, consisting of only 2 articles, one of which defined the basic principles of the system in 5 paragraphs. It assumed a temporary dominant position of the parliament - Sejm, defining it as 'a sovereign power' with indefinite term of office and the Chief of State was formally subordinated and responsible before the Sejm.

In 1921, the March Constitution ${ }^{64}$ was passed and entered into force the following year. The March Constitution was one of the many democratic basic laws which arose at that time in the countries that gained independence after war. It drew on the French Third Republic model and, unfortunately, soon consolidated its flaws in the Polish laws, e.g., unstable cabinets based on fragile multi-party alliances. Certainly, the March Constitution was open, liberal in tone, and displayed a broad catalogue of civic rights (an extensive chapter V). According to the preamble, which stressed the continuity of the constitutional tradition, the aim of the new order was to consolidate 'independence, power, security, and social order' on the basis of the rule of law and freedom, to ensure 'the development of all moral and material forces for the benefit of the entire reviving humanity', and to ensure equality 'for all citizens.'

The March Constitution introduced a relatively balanced tripartition of power (although with a noticeable dominance of legislative power), entrusting the power to "pass all public and private laws' to the bicameral parliament (the Sejm and the Senate). The electoral law of the autumn of $1918^{65}$ was for the first time in Polish history common in character, introducing only the restriction of age (21 and 25). The functions of the upper house, the Senate, did not balance the powers of the Sejm. Senate amendments were repealed by

${ }^{62}$ According to the 1921 census, Poles constituted 69.2\%, Ukrainians 14\%, Jews $7.8 \%$, Belarusians 3.9\%, Germans 3.8\%.

${ }^{63}$ Formally: Resolution of the General Sejm of 20 February 1919 on entrusting Józef Piłsudski with the further exercise of the office of the Chief of State (Dziennik Praw Państwa Polskiego [Journal of Laws of the Polish State, further as: Journal of Laws] No. 19, item 226).

${ }^{64}$ The Constitutional Act of 17 March 1921 (Journal of Laws of the Republic of Poland No. 44, item 267).

${ }^{65}$ Decree on the Electoral Law for the Sejm of 28 November 1918 (Dekret o ordynacji wyborczej do Sejmu Ustawodawczego, Journal of Laws, no. 18, item 46). 
the Sejm with a specific majority of $11 / 20$. For the first time the heterogeneous concept of nation was adopted on the constitutional level.

The significant changes adopted in August Novelization of the Constitution, i.e. in the Act of 2 August $1926^{66}$ came into force as result of the coup d'état organized in May by Marshal Józef Piłsudski`s political camp. These events disrupted the delegation chain. Parliament remained a representative body but was in fact devoid of decision-making powers. The amendment shifted the scope of the current relative balance between the authorities, strengthening the executive power, e.g., the introduction the possibility of the actual adoption of the budget without the decision of the Sejm, limiting the vote of no confidence, and the presidential right to dissolve the chambers before the end of the term (new wording of Articles 25 and 26). It was also the President who was empowered to issue statutory orders at the time when the Sejm and Senate were dissolved until the time of the re-assembly of the Sejm, in the case of urgent state necessity.

On the same day, 2 August 1926, the Sejm passed a law authorising the President of the Republic of Poland to issue statutory orders. ${ }^{67}$ This act outlined the limits of the authorisation in question very broadly - it referred to the scope of 'bringing laws in force into line with the Constitution and executing its provisions, providing for the issuance of separate laws, reorganisation, and simplification of the legal status in Poland, the administration of justice and social benefits (...), the repair of the economic status in Poland (...).' The executive became a competitive legislative centre, in opposition to the Parliament, which became the centre of the opposition.

Law-making competences were partially detached from the nation represented by the parliament. This peculiar dual power system, splitting up the law-making delegation into the weakened parliament and the president, ${ }^{68}$ was to last until 1935. The Piłsudski political movement was quite blunt about striving for a profound revision of the political system. The new constitution was adopted with a violation of the prescribed procedure. ${ }^{69}$ The April Constitution (the Constitutional Act of 23 April 1935 ${ }^{70}$ ) was intended to give Piłsudski full power, however and highly ironically, it was the last official act which he signed. Piłsudski, the hero of the 1920 independence activities and the war with Russia, the author of the 1926 coup d'état, twice the Prime Minister, and the Minister of Military Affairs continuously after 1926, died on 12 May 1935 as a consequence of a serious illness.

The April Constitution, written in exceptionally clear and consistent language, is undoubtedly a basic law that introduces an authoritarian model of government. The first 10 articles (Chapter: the Republic of Poland) dispel any possible doubts. The 'decalogue' refers to a strictly solidarity-based model of community (the state is the 'common good of

66 Journal of Laws of the Republic of Poland no. 78, item 442.

67 Journal of Laws of the Republic of Poland no. 78, item 443.

${ }^{68}$ Piłsudski himself, aware of the need to legitimise the activities that he carried out, put forward his candidacy in the presidential elections held in the merged chambers, the so-called National Assembly. He obtained the required number of votes, but he did not become president himself, and instead presented another candidate to the chambers. However, the election itself may be interpreted as granting a sui generis vote of confidence.

691933 the draft was adopted in the Sejm, when the outraged opposition left the Chamber after the presentation of the so-called 'constitutional theses'. This way the Piłsudski fraction achieved the required majority and decided to conduct the voting immediately. In consequence, even the constitution-making power had been detached from the real representative body.

70 Journal of Laws of the Republic of Poland. no. 30, item 227. 
all citizens', the obligation of 'each generation' to enhance 'the strength and dignity of the state', for which it is responsible 'before the posterity its honour and name'). The life of society was to be shaped 'within the state and on the basis of the state' [Article 4(1)], while the state was to ensure 'free development of society, and when the common good so requires, it was to direct it or regulate its conditions' [Article 4(2)]. Individual creativity remained a 'lever of collective life' and the state was to provide the citizens with 'the opportunity to develop their personal values and freedom of conscience and expression' (Article 5). The limit of freedom is the 'common good2. According to Article 7, 'the citizen's entitlement to influence public affairs shall be measured by the value of his/her effort and contribution to the common good.' It was not just a mere announcement - such an exclusive character was soon given to the new electoral law for the Senate, limiting the circle of voters to a few special categories. The state was to strive to 'unite all citizens in a harmonious collaboration in order to promote the common good' (Article 9). Finally, 'no action may run counter to the objectives of the State as expressed in its laws. (...) In the event of resistance, the State shall take coercive measures' (Article 10).

Since 1935, the President of the Republic of Poland had remained the key political body under the rule of law. He was vested with the 'responsibility towards God and history for the fate of the State', while his 'primary duty' was to be the 'care for the good of the state, readiness to defend, and position among the nations of the world.'

Presidential decrees were explicitly mentioned as one of the types of 'legislative acts'. Apart from the provisions reiterating the assumptions of the August Novelization of 1926, the April Constitution included an even more far-reaching provision: the organisation of the government, authority over the Armed Forces (by the way, recognised as one of the 'organs of the state remaining under the authority of the President', Article 3) and the organisation of the government administration could henceforth be regulated exclusively by a presidential decree, issued without any time limit (Article 56).

Prima facie, it is very easy to put the April Constitution in opposition to the model of the March Constitution (heterogeneity). Certainly, the legislator, with reference to the new basic law, tried to include a certain concept of the nation as a community strongly bound by solidarity, shaping the future together, and on the other hand, with specific provisions of the Constitution it secured itself the tools for shaping this community.

However, it is necessary to emphasise that contrary to the anti-democratic processes taking place simultaneously in the countries of Central and Western Europe, Piłsudski's real efforts were not aimed at emphasising the ethnic component. Quite on the contrary, the political forces of the so-called National Democracy stressed the key importance of the ethnic community in accordance with the assumptions of their leader Roman Dmowski and for years remained hostile to Piłsudski, who originated from the socialist party. The phrase 'The Polish Nation' cannot be found in the April Constitution; the legislator only used the phrases 'citizens' and 'The Polish State'. Piłsudski, being a propagator of the inclusive concept of the Polish state and society, also called Jagiellonian, was afraid of reducing the concept of 'nation' in the interpretation of the Constitution to an exclusively ethnic factor.

Thus, Piłsudski's concept is an unexpectedly open, state-oriented structure, conditioned by Poland's specific geopolitical location and changes taking place abroad. Facing democratic inefficiencies till 1926 (short-term rule of individual governments, unstable coalitions mainly resulting from parliamentary fragmentation), he noticed a need to strengthen state power, but also with the utilisation of the strength of citizen involvement. At the same time, the political practice of the interwar period does not fully reflect these 
assumptions. This is contradicted by the approach to national (especially Ukrainian ${ }^{71}$ ) and religious-national minorities (Jews ${ }^{72}$ ).

Piłsudski was a charismatic Chief of State, predestined for the presidential office. This model did not however serve Piłsudski due to his death. The presidential system in fact was not put into practice completely. Competitive and mutually neutralising centres of power had been established, this unexpectedly protected the country from the dictatorship of the individual. It can be argued that it was other factors (mainly the ineffectiveness of the political system) rather than the homogeneous concept of a nation, despite its presence in political theories of e.g. National Democracy, that proved to be a real threat to democracy in the interwar period. This period is characterised by the clash of two concepts of the nation. However, this friction was not directly reflected in the constitutions.

\section{THIRD REPUBLIC (1989-): BETWEEN HOMOGENEOUS OR HETEROGENEOUS CONCEPT?}

Symptoms of shaping an open (heterogeneous) nation can be seen at the beginning of the transition to democracy (1989). The Round Table agreement was and still is a symbol of the consensus made by the government and the opposition. The ideas of political pluralism, the separation of powers and the free elections were constitutionalised as a result of the agreement. These concepts replaced the dominant role of the party (Polska Zjednoczona Partia Robotnicza/Polish United Workers' Party), the unity of state powers with the Sejm as the supreme body (subordination of state organs to the Sejm) and the façade general election.

Thus, the subsequent phases of the open (heterogeneous) nation building process can be linked to Polish constitutions. Firstly, in 1989, the Constitution of 1952 was transformed and adjusted to the new democratic state. Then, the Interim Constitution of $1992^{73}$ provided the idea of self-government. Citizens and their communities as well as the individuals as a forefront of the state powers became the central idea in place of etatism. Finally, the principle of subsidiarity was introduced directly in the 1997 Constitution. Analysing the

71 For example, the Act on Local Government of 1922, which provided, among other things, for the establishment of a binational provincial self-government and a Ukrainian university in the southeastern part of the country, was not implemented. See: Act of 26 September 1922 on the principles of the general, provincial local government, in particular Lwów, Tarnopol and Stanisławów provinces (Journal of the Laws of the Polish Republic, no 90, item 829). In 1931, Piłsudski entrusted the normalisation of tense Polish-Ukrainian relations in the south-eastern provinces to Minister Bronisław Pieracki. The actions undertaken by Pieracki seemed promising, but the radical organizations of Ukrainian nationalists did not want an agreement. In 1934 they organized an assassination attempt on the minister who died as a result of gunshot wounds. Garlicki (2008) 232-45. On the attitude of the Polish political fraction towards the Ukrainian issue. also: Stoczewska (2013) 171-342.

${ }^{72}$ Here we can recall the numerus clausus practice, i.e. restrictions on the university enrolment with respect to students of Jewish descent (Ogonowski (2012) 130-31) and the so-called ghetto benches, introduced by the rectors of some universities in response to the demands of student nationalist organizations. This practice was sanctioned in 1937 by the Minister of Religious Denominations and Public Enlightenment (he permitted the so-called 'Aryan paragraph' in the statutes of student associations ( $\S 3$ (2) of the Ordinance of 14 October 1937 on academic associations, Journal of Laws of Polish Republic, no 78 item 572). Some students and professors opposed such actions, which led to numerous riots during lectures and in the streets of university cities.

73 Dz. U. $1992 \mathrm{nr} 84$ poz. 426 [Journal of Law 1992 No 84 item 426]. 
Constitution of 1997, the concept of an open and inclusive nation is clearly visible. Using the phrases of the preamble, 'the Polish Nation' can be identified which is not ethnic, ${ }^{74}$ for being a member of the nation, religion is irrelevant ${ }^{75}$ and Christianity is not a value which excludes others. ${ }^{76}$ Polish citizens are equal ${ }^{77}$ and have an inclusive approach. ${ }^{78}$ The Constitution relates also to the balanced time perspective ${ }^{79}$ that allows for stable development. However, this ideal picture of the Polish nation should be confronted with the reality. It can be noticed that there are certain constitutional provisions that have never been implemented in practice. As an example is the Article 72(2) where according to the provision the relation between parents and children is described as parental care. In addition, Article 48 refers to parental rights. Both categories are not connected to subordination and refer to equality. Nevertheless, the regulation of the Family and Guardianship Code of 1964 directly applies the formula of parental authority (section 2). This authority is strongly connected to subordination, which means that subjects in the scope of such relation are not equal. Another example relates to religious education at school. According to Article 53(4), the religion of a church or other legally recognized religious organization may be taught in schools, but other peoples' freedom of religion and conscience should not be infringed thereby. This means that every religion should have equal access to educate and to be taught. However, in day-to-day practice, the religion of the Catholic Church is taught whilst the teaching of other religions or ethics is relatively rare. ${ }^{80}$ This is not surprising when about $90 \%$ of Polish population declare itself to be a Catholic. Nevertheless, the religious education of other religions may be difficult to organise when there should be at least 7 pupils to be taught in one group. ${ }^{81}$ Such coexistence of two different perspectives (constitution and practice) can be recognized as a struggle of two concepts of the nation heterogeneous according to the Constitution and homogeneous in the practice.

74 'We, the Polish Nation - all citizens of the Republic, Art. 4 - Supreme power in the Republic of Poland shall be vested in the Nation'.

75 'Both those who believe in God as the source of truth, justice, good and beauty, as well as those not sharing such faith but respecting those universal values as arising from other sources'.

76 'For our culture rooted in the Christian heritage of the Nation and in universal human values'.

77 'Equal in rights and obligations towards the common good - Poland'.

78 'Bound in community with our compatriots dispersed throughout the world, aware of the need for cooperation with all countries for the good of the Human Family. Art. 6 - The Republic of Poland shall provide assistance to Poles living abroad to maintain their links with the national cultural heritage. Art. 27 - Polish shall be the official language in the Republic of Poland. This provision shall not infringe upon national minority rights resulting from ratified international agreements'.

79 'Beholden to our ancestors (recalling the best traditions of the First and the Second Republic, obliged to bequeath to future generations) for their labours, their struggle for independence achieved at great sacrifice'.

80 Statistics say that $87 \%$ of pupils attend the Catholic Church classes, Ponad 87 proc. dzieci i młodzieży uczęszcza na lekcje religii (2016) link 1.

81 Para. 2 of regulation of Ministry of Education (14 kwietnia 1992 r. w sprawie warunków i sposobu organizowania nauki religii w szkołach publicznych, Dz.U. $1992 \mathrm{nr} 36$ poz. 155 [April 14, 1992 on the conditions and manner of organizing religious education in public schools, Journal of Law 1992 No. 36 item 155]). 
The general election held in 2015 brought about a change in the parliamentary majority. The transformation of the political system towards an illiberal democracy ${ }^{82}$ began. An informal amendment of the Constitution ${ }^{83}$ had been used for systemic transformation, as the Law and Justice party did not achieve a constitutional majority. In consequence, it became clear that the values promoted by the 1997 Constitution have been abandoned. Those in power employ clear exclusionary narratives with regard to the concept of a nation. The most visible example is connected to the Constitutional Tribunal (CT) justices selected by the outgoing Sejm in 2015. Especially, the three who were selected according to the Constitution ${ }^{84}$ still stay without being sworn in by the President. ${ }^{85}$ In connection to the CT practice, another example is worth pointing out is the clear exclusionary message can be seen in the dissenting opinion of Justice Muszyński in relation to the Ombudsman. ${ }^{86}$ The Justice call literally for the dismissal of the Ombudsman. It is obvious to everybody that the Ombudsman acts in accordance with the 1997 Constitution and not in accordance with the political will of the ruling majority. Additionally, day-to-day practice has become an exclusion of the opposition e.g., from legislative process. ${ }^{87}$ The demotion act of 2018 (vetoed by the President) symbolises the moral exclusion of the predecessors from the People's Republic of Poland because in some cases the demotion concerned people after their death e.g., Wojciech Jaruzelski. ${ }^{88}$ In relation to the topic of this analysis, the most important example is connected to The Act on the Institute of National Remembrance and its novelisation dated on 26 of January 2018 which introduced a new type of offence. ${ }^{89}$ The situation caused a sharp reaction from Israel and the USA. Consequently, the provision was invalidated on 27 June $2018 .^{90}$ It is important that the legislative power designated 'the Polish Nation' as a homogeneous entity consist of good people only. Such an approach

82 Drinóczi and Bień-Kacała, (2019, under publication).

83 Bień-Kacała (2017) 199-218.

84 The Constitutional Tribunal judgment of 3 December 2015 (K 34/15).

85 Bień-Kacała (2016).

86 See decision of the CT, 22 March 2018 r., K 9/16 and dissenting opinion of Justice M. Muszyński who ask for dismissal of the Ombudsman because of acting against the Ombudsman's oath. See also Grzelak (2018) link 2. The Author presents her opinion in favour of the Ombudsman owing to her occupation of the Ombudsman's Office. However, she gives many examples of exclusionary approach.

87 E.g., voting on the state budget and the decommunization law when the parliamentary majority gathered and voted outside the main chamber which was blocked by the opposition for 30 second per MP during the hearing of a bill.

${ }^{88}$ Rządowy projekt ustawy o pozbawianiu stopni wojskowych osób i żołnierzy rezerwy (2018) link 3.

89 Article 55 a: Whoever publicly and contrary to the facts attributes to the Polish Nation or to the Polish State responsibility or co-responsibility for the Nazi crimes committed by the German Third Reich, as specified in Article 6 of the Charter of the International Military Tribunal - Annex to the Agreement for the prosecution and punishment of the major war criminals of the European Axis, executed in London on 8 August 1945 (Journal of Laws of 1947, item 367), or for any other offences constituting crimes against peace, humanity or war crimes, or otherwise grossly diminishes the responsibility of the actual perpetrators of these crimes, shall be liable to a fine or deprivation of liberty for up to 3 years. The judgment shall be communicated to the public.

90 See both statutes: Instytut Pamięci Narodowej - Ustawa (1018) link 4. 
is directly connected to the narrative of the education at Polish school that promote an idealised Polish history, ${ }^{91}$ and in consequence, an idealised homogeneous entity.

Thus, we would like to emphasise that, despite the open constitutional axiology, political practice has been moving and continues to move towards a strong polarisation of society. The polarization intensified after the presidential plane crash in Smolensk in 2010. The 'resultant political soil' turned out to be fertile, as after the adoption of the constitution in 1997 the nation has not been consolidated in a political (heterogeneous) sense. According to Matyja, 'abandoning communism required [....] something more than only restoring the free market and the rules of democratic competitiveness - it required the creation of a political nation and formation of state citizens. [....] A political nation - one from the first verses of the Constitution, i.e. 'all citizens of the Republic' - was to live the life of a cultural nation, treating all differences as statistically marginal.' 92

A culturally homogeneous nation was to be the foundation of a democratic republic and as a result, political polarization has increased which, instead of civic integration and political rivalry based on the principles of the Constitution, made the 'political rivals' appear as 'enemies'.

These tendencies for polarization and exclusion can even be seen in the statements of the centre-right Civic Platform, which is declaratively attached to the principles of liberal democracy. Donald Tusk distinguished normal citizens from the 'mohair coalition', ${ }^{93}$ whereas Bronisław Komorowski separated 'the rational' from 'the radicals'. ${ }^{4}$ These statements are reflected in a radicalised version in the words of the current Civic Platform leader Grzegorz Schetyna:

We must win these elections, mobilise all positive forces in order to shake the Law and Justice locust off the healthy tree of our country. ${ }^{95}$

The reference to the homogeneous concept of the nation is particularly evident in the rhetoric of Law and Justice, a party which has been in power since 2015, especially when its leader describes political opponents as 'Poles of an inferior kind'96 or 'treacherous mugs' ${ }^{97}$ In an interview in 2018, Jaroslaw Kaczyński states that difficulties in governing and reforming the state stem, among other things, from the fact that 'everywhere we come across people who have a huge deficit of national awareness' ${ }^{98}$ This is associated with an ambivalent attitude towards the rule of law, which was expressed by Prime Minister

91 Bilewicz (2018) 1-8.

92 Matyja (2018) 6.

93 'Mohair berets' refers to the listeners of the traditionalist and extreme right-wing religious radio 'Radio Maryja', while 'mohair coalition' refers to the informal (by 2005) coalition of the rightwing-populist coalition (PiS [Law and Justice], Samoobrona [Self-Defence], and Liga Polskich Rodzin [League of Polish Families]). The term 'mohair' in Donald Tusk's statement has in this context pejorative connotations and introduces a difference between 'mohairs' and 'millions of Poles'. Sejm RP, 5 kadencja, 2 posiedzenie, 2 dzień, 10.11.2005 (2005) link 5.

94 Nowakowska and Bielecki (2015) link 6.

95 Schetyna (2018) link 7.

96 Kaczyński (2018) link 8.

97 Kaczyński (2017) link 9.

98 Baranowska and Kaczyński (2018) 20. A homogeneous understanding of democracy is consistent with the fact of the addressing of C. Schmitt by J. Kaczyński as a realistic and interesting author, see Kaczynski (2017) link 10. 
Mateusz Morawiecki when he stated that 'it's not only the law, but also justice that is important. We have had very little justice in Poland in the 25 years of transformation. And bad people have been hiding behind the law. ${ }^{\text {'9 }}$ The categories of 'bad people' and 'national awareness' are flexible and can be used to belittle political opponents by denying them the right to represent the nation.

Thus, the strategy of building public support by the two main Polish political powers refers to strong distinctions, which allow the Poles to be assigned to a 'good' or 'bad' group. ${ }^{100}$ It seems, therefore, that strong polarization is present in political discourse regardless of political affiliation. In journalism it is described as a 'war between two tribes' in which two homogeneous beings are engaged: the 'real nation' against 'normal Poles'.101 If it was assumed that this is the case, then in such a situation the democratic constitution would cease to be a medium of civic integration. Political institutions and procedures would only serve to defeat the 'enemy' to whom the worst intentions are assigned. ${ }^{102}$

Therefore, beyond any doubt, these polarizing factors and homogenizing tendencies do exist in the Polish political and systemic practice. They contradict the principles and values of the Constitution, i.e., the idea of an open and inclusive democracy in which political pluralism is natural, and political rivalry does not mean striving for 'ultimate victory and domination'. Polarization and homogenization hinder the development of the heterogeneous concept of a nation contained in the constitution, because instead of the idea of citizenship, they emphasize what divides citizens (belonging to 'tribes'). From the point of view of a 'tribe member', democratic legislation is legitimate only when it is passed by 'my tribe', and when it is passed by the 'other tribe' it is only a coercion. What matters here is not constitutional procedures, but representation based on a strong political identity that generates the distinction between 'us and them' or 'friends and enemies'. The constitutionally defined delegation chain is in a way 'replaced' by a chain determined by the 'tribe' to which it belongs.

The above mentioned state of 'war between two tribes' is not so much a description as an emphasising of existing political phenomena. Such an enhanced picture allows the pinpointing of the danger of constitutional democracy, when polarizing and homogenizing tendencies start increasing. What will happen when Polish political practice follows the ideas of Dmowski rather than Kelles-Krauz, i.e., when 'national ethics' and not the nation of 'all citizens' becomes the basis for the delegation chain. An informal constitutional change could be identified by reinterpreting the first element of the delegation chain and as a result, the model of a democratic legislative delegation contained in the constitution will be transformed from 'open' (based on deliberation and competition) to 'closed' (based on the 'will of the whole nation'). A written constitution would then be superseded by the real one. ${ }^{103}$ Such a change in the understanding of the 'nation' would also result in a formal preservation of the 'nation-representative body' delegation, but it loses its significance in the face of the reconstruction of the first element of the delegation chain. As a result, the parliament (de jure the exclusive legislator) no longer represents all the electorate/the nation, but de facto becomes a tool of the ruling political party.

99 Morawiecki (2017) link 11.

100 A fierce political dispute that divided society has been the 'political fuel' for two main antagonistic powers (Law and Justice and Civic Platform), see Krassowski (2016).

101 See e.g., Janicki and Władyka (2017) link 12.

102 See Włoch (2015) A34.

103 See Lassalle (1901). 


\section{CONCLUSIONS}

In this paper, the idea of law-making delegation was described in the context of homogeneous and heterogeneous concepts of a nation. Using the constitutional, it was initially showed how law-making competences in the period of the Second Republic were partly detached from the nation represented by parliament.

Two interwar constitutions were juxtaposed that established very different political regimes - a fully democratic and an authoritarian one. Although both were essentially an inclusive concept of the nation, in the case of the April Constitution the delegation chain was disrupted. In this case, the delegated power was usurped by a body with disputed democratic legitimisation.

The situation is now different under the constitution of 1997. It was shown how a certain concept of the nation present in the constitutional practice may affect the meaning of constitutional provisions. The visible examples can be found especially since the 2015 general election. Nevertheless, it is not claimed that either the elements of homogeneity or the elements of heterogeneity are dominant in Poland. However, these dominants at certain moment may lead to some reinterpretation of the constitution, especially when the constitution is based on open and pluralistic axiology. In our opinion, such reinterpretation might be dangerous for democracy. A threat for democracy might be also the homogenizing tendencies present in the application of the constitution. Certain practices might lead to polarization, dividing society between the so-called 'real members of the nation' ('true' members) and 'nominal members' ('untrue' ones). In such a case, there would be a radical reinterpretation of the entire chain of delegation, i.e. the legislator would express the will of a 'real nation' that could be identified by ethnic, cultural, or religious criteria. The place of 'the Polish Nation - all citizens of the Republic' would be now occupied by a new homogeneous formation, and that would mean an informal change of the constitution because the entity holding the highest authority would change as well.

Therefore, when referring to the concept of a heterogeneous and homogeneous nation, we have focused on the course of the delegation chain in Polish constitutions. While in the case of historical acts we dealt with classic disturbances of the chain (separation of a fragment of the delegated power by taking it over by the executive), in the case of the 1997 Constitution, the disturbance of the chain took on a different form - the transformation of the significance of the first link. This may result in a material change of the constitution itself.

\section{LITERATURE}

Baranowska, Kamila and Kaczyński, Jarosław, 'Polska nie będzie płaciła podatku od niemieckich zbrodni' (Poland will not pay tax on German crimes) (2018) 7/260 Do Rzeczy 16-20.

Bień-Kacała, Agnieszka, 'Informal constitutional change: the case of Poland' (2017) 6 Przegląd Prawa Konstytucyjnego 199-218.

Bien-Kacała, Agnieszka, 'Polish Constitutional Tribunal: a systemic reform or a hasty political change', (2016) 1 DPCE.

Bilewicz, Michał, 'Między idealizacją a hiperkrytycyzmem. Polska niepamięć historyczna i jej źródła' (Between idealization and hypercritism. Poland historical oblivion and its sources) (2018) Instytut Studiów Zaawansowanych, Seria ANALIZY, 1-9.

Bryant, Christopher G. A., 'Civic Nation, Civic Society, Civic Religion' in Hall, John A. (ed.), Civil Society. Theory, History, Comparison (Polity Press 1995) 136-57.

Canovan, Margaret, People (Polity Press 2005).

Dahl, Robert A., Democracy and its Critics (Yale University Press 1989).

Dmowski, Roman, 'Kościół, naród, państwo' (The Church, Nation, State) in Dmowski ,Roman, Wybór pism (Vol. 1, Zysk i S-ka Wydawnictwo 2014) 755-82. 
Dmowski, Roman, 'Myśli nowoczesnego Polaka' (Thoughts of modern Pole] in Dmowski, Roman, Wybór pism (Vol. 1, Zysk i S-ka Wydawnictwo 2014) 11-140.

Drinóczi, Tímea and Bień-Kacała, Agnieszka, 'Constitutions and constitutionalism captured: shaping illiberal democracies in Hungary and Poland' (2019, under publication), German Law Journal.

Garlicki, Andrzej, Piękne lata trzydzieste (Beautiful Thirties) (Prószyński i S-ka 2008).

Gellner, Ernest, Nations and Nationalism (Basil Blackwell 1983).

Guérot, Ulrike, Warum Europa eine Republik werden muss! Eine politische Utopie (Verlag J.H.W. Dietz Nachf. 2016).

Habermas, Jürgen, Between Facts and Norms. Contributions to a Discourse Theory of Law and Democracy (trans. W. Rehg, The MIT Press 1996).

Hamilton, Alexander, Madison, James and Jay, John, The Federalist with The Letters of 'Brutus' (ed. T. Ball, Cambridge University Press 2003).

Hobsbawm, Eric J., Nations and nationalism since 1780. Program, myth, reality (Cambridge University Press 2000).

Kant, Immanuel, 'On the Common Saying: This May Be True in Theory, but It Does Not Hold in Practice' in Immanuel Kant, Toward Perpetual Peace and Other Writings on Politics, Peace, and History (trans. D. L. Colclasure, Yale University Press 2006) 44-66.

Kant, Immanuel, 'Toward Perpetual Peace: A Philosophical Sketch' in Kant, Immanuel, Toward Perpetual Peace and Other Writings on Politics, Peace, and History (trans. D. L. Colclasure, Yale University Press 2006) 66-109.

Kelles-Krauz, Kazimierz, 'Krytyka zasady narodowości' (Critic of nationality principle) in KellesKrauz, Kazimierz, Naród $i$ historia. Wybór pism, (ed. S. Ciesielski, Państwowy Instytut Wydawniczy 1989) 303.

Kelles-Krauz, Kazimierz, 'Niepodległość polski a materialistyczne pojmowanie dziejów' (Polish independence and materialistic understanding of history) in Kelles-Krauz, Kazimierz, Naród $i$ historia. Wybór pism (ed. S. Ciesielski, Państwowy Instytut Wydawniczy 1989) 334-60.

Kelles-Krauz, Kazimierz, 'W kwestii narodowości żydowskiej' (On the issue of Jewish Nationality) in Kelles-Krauz, Kazimierz, Naród i historia. Wybór pism (ed. S. Ciesielski, Państwowy Instytut Wydawniczy 1989) 308-33.

Kelsen, Hans, 'Absolutism and Relativism in Philosophy and Politics' (1948) 5 The American Political Science Review 906-14.

Krassowski, Robert, Czas Kaczyńskiego. Polityka jako wieczny konflikt (Kaczyński's time. Politics as an Eternal Conflict) (Czerwone i Czarne 2016).

Lassalle, Ferdinand, 'Über Verfassungswesen' in Lassalle, Ferdinand, Gesamtwerke (ed. E. Blum, Pfau 1901).

Lefort, Claude, 'The Question of Democracy' in Lefort, Claude, Democracy and Political Theory (trans. D. Macey, Polity Press 1988) 9-20.

Manin, Bernard, The principles of representative government (Cambridge University Press 1997).

Matyja, Rafał, Wyjście awaryjne. O zmianie wyobraźni politycznej (Emergency Exit. About Changing the Political Imagination) (Karakter 2018).

Mill, John Stuart, 'Consideration on Representative Government' in John Stuart Mill, Essays on Politics and Society, Collected Works of John Stuart Mill, Vol. XIX (University of Toronto Press 1977) 371-613.

Mouffe, Chantal, The Democratic Paradox (Verso 2000).

Mounk, Yascha, The People vs. Democracy. Why Our Freedom Is in Danger and How to Save It (Harvard University Press 2018).

Müller, Jan-Werner, Constitutional Patriotism (Princeton University Press 2007).

Müller, Jan-Werner, What is Populism? (University of Pennsylvania Press 2016).

Nussbaum, Martha C., The New Religious Intolerance. Overcoming the Politics of Fear in an Anxious Age (The Belknap Press of Harvard University Press 2012).

Ogonowski, Jerzy, Sytuacja prawna Żydów w Rzeczypospolitej Polskiej 1918-1939. Prawa cywilne i polityczne (Legal situation of the Jews in Poland 1918-1939. Civil and constitutional laws) (Żydowski Instytut Historyczny im. Emanuela Ringelbluma 2012).

Przeworski, Adam, Democracy and the Limits of Self-Government (Cambridge University Press 2010). 
Rawls, John, Political Liberalism (Columbia University Press 1993).

Rousseau, Jean-Jacques, 'The Social Contract' in Rousseau, Jean-Jacques, The Social Contract and

The First and Second Discourses (trans. S. Dunn, Yale University Press 2002) 149-254.

Saward, Michael, Democracy (Polity Press 2003).

Schmitt, Carl, Constitutional Theory (trans. J. Seitzer, Duke University Press 2008).

Schmitt, Carl, Legality and Legitimacy (trans. J. Seitzer, Duke University Press 2004).

Schmitt, Carl, Roman Catholicism and Political Form (trans. G. L. Ulmen, Greenwood Press 1996).

Schmitt, Carl, The Concept of the Political (trans. G. Schwab, The University of Chicago Press 1996).

Schmitt, Carl, The Crisis of Parliamentary Democracy (trans. E. Kennedy, The MIT Press 2000).

Schnapper, Dominique, Community of Citizens. On the Modern Idea of Nationality (trans. S. Rosée, Transactions Publishers 1998).

Sieyès, Emmanuel Joseph, 'What Is the Third Estate?' in Sieyès, Emmanuel Joseph, Political Writings. Including the Debatte between Sieyès and Tom Paine in 1791 (trans. M. Sonenscher, Hackett Publishing Company Inc. 2003) 92-162.

Snyder, Timothy, Nationalism, Marxism, and Modern Central Europe. A Biography of Kazimierz Kelles-Krauz (1872-1905) (Harvard University Press 1997).

Stoczewska, Barbara, Ukraina i Ukraińcy w polskiej myśli politycznej. Od końca XIX wieku do wybuchu II wojny światowej (Ukraine and Ukrainians in Polish Political Thought. From the End of the 19th Century until the Outbreak of World War II) (Krakowskie Towarzystwo Edukacyjne sp. z o.o. - Oficyna Wydawnicza AFN 2013).

Strøm, Kaare, Müller, Wolfgang C. and Bergman, Torbjörn, 'Parliamentary Democracy: Promise and Problems' in ed. Strøm, Kaare, Müller, Wolfgang C. and Bergman, Torbjörn, Delegation and Accountability in Parliamentary Democracies (Oxford University Press 2006) 3-32.

Walicki, Andrzej, 'The Troubling Legacy of Roman Dmowski' (2000) 14/1 East European Politics and Societies 12-46.

Weber, Max, 'Objectivity' in Social Science and Social Policy' in Weber, Max, The Methodology of the Social Sciences (trans. E. A. Shils and H. A. Finch, The Free Press 1949) 50-112.

Włoch, Wojciech, 'Logika wykluczenia' (The logic of exclusion) (2015) 246 Dziennik Gazeta Prawna A34.

\section{LINKS}

1. Ponad 87 proc. dzieci i młodzieży uczęszcza na lekcje religii (2016) <https://ekai.pl/ponad-procdzieci-i-mlodziezy-uczeszcza-na-lekcje-religii/> accessed 27 January 2019.

2. Grzelak, Agnieszka: Choosing between two Evils: the Polish Ombudsman's Dilemma (2018) $<$ https://verfassungsblog.de/choosing-between-two-evils-the-polish-ombudsmans-dilemma/ $>$ accessed 27 January 2019.

3. Rządowy projekt ustawy o pozbawianiu stopni wojskowych osób i żołnierzy rezerwy (2018) $<$ http://www.sejm.gov.pl/sejm8.nsf/PrzebiegProc.xsp?nr=2319> accessed 27 January 2019.

4. Instytut Pamięci Narodowej - Ustawa (1018) <https://ipn.gov.pl/pl/o-ipn/ustawa/24216,Ustawa. html $>$ accessed 27 January 2019.

5. Sejm RP, 5 kadencja, 2 posiedzenie, 2 dzień, 10.11 .2005 (2005) <http://orka2.sejm.gov.pl/ Debata5.nsf/main/34EACE52> accessed 27 January 2019.

6. Nowakowska, Agata and Bielecki, Tomasz, Prezydent nazywa spór o Polskę. Radykalna czy racjonalna (2015) < $<$ ttp://wyborcza.p1/1,76842,17641487,Prezydent_nazywa_spor_o_Polske_ Radykalna_czy_racjonalna.html> accessed 27 January 2019.

7. Schetyna: Polacy muszą żyć ze świadomością, że Polską rządzi premier kłamca i tchórz (2018) $<$ https://www.tvn24.pl/wiadomosci-z-kraju,3/schetyna-na-konwencji-regionalnej-koalicjiobywatelskiej-w-poznaniu,875820.html> accessed 27 January 2019.

8. Kaczyński: 'Resortowe dzieci się bronią. Ich twierdza to Trybunał Konstytucyjny' (2018) <http:// wyborcza.pl/1,75398,19334126,kaczynski-resortowe-dzieci-sie-bronia-ich-twierdza-to-trybunal. html $>$ accessed 27 January 2019.

9. Kaczyński: Uważam, że dobrze uczyniłem (2017) <https://www.rp.pl/Prawo-i-Sprawiedliwosc/ 170718849-Jaroslaw-Kaczynski-Uwazam-ze-dobrze-uczynilem.html> accessed 27 January 2019. 
10. Kaczynski: 'Es gilt, dass Frau Merkel für uns das Beste wäre' (2017) <https://www.faz.net/ aktuell/politik/ausland/kaczynski-wuenscht-sich-fuer-polen-einen-sieg-merkels-14859766.html> accessed 27 January 2019.

11. Morawiecki w DW: Prawo nie jest najważniejsze (2017) $<$ https://www.dw.com/pl/mateuszmorawiecki-w-dw-prawo-nie-jest-najwa\%C5\%BCniejsze/av-37582962> accessed 27 January 2019.

12. Janicki, Mariusz and Władyka, Wiesław, Bajka o dwóch plemionach (2017) <https://www. polityka.pl/tygodnikpolityka/kraj/1694980,1,pis-kontra-opozycja-czyli-propaganda-wieczniezywa.read $>$ accessed 27 January 2019. 